\title{
Diskusi Nilai Etika dari Hadih Maja dalam Konseling Model KIPAS dengan Tema Kecakapan Sosial
}

\author{
Muqarramah Fitri $^{1}$, Andi Mappiare-AT ${ }^{1}$ Triyono $^{1}$ \\ ${ }^{1}$ Bimbingan dan Konseling-Universitas Negeri Malang
}

\begin{tabular}{l} 
INFO ARTIKEL \\
\hline Riwayat Artikel: \\
Diterima: $18-10-2019$ \\
Disetujui: $13-08-2020$ \\
\hline
\end{tabular}

Kata kunci:

discussion;

ethich value;

hadih maja;

social skills:

diskusi;

nilai etika:

hadih maja;

kecakapan sosial

\begin{abstract}
ABSTRAK
Abstract: Hadih Maja is figurative word nèk tu (ancestor) which is made as a way to admonish smoothly and meaningfully to configurate students' behaviour in accordance with the custom in Aceh. The purpose of this study was to describe the ethical values in Hadih Maja. The results of this study were implemented into the process of conducting discussions technique to modify students' social skills. This study used a qualitative research method whit the multilevel Hermeneutics analysis. Besed on data analysis, there were 11 ethical values in Hadih Maja. Ethical values in Hadih Maja obtained are catagorized into social sub themes. The process of implementing the discussion technique in this study used a 5 stage KIPAS counseling model (adaptive progressive and structural intensive counseling).
\end{abstract}

\begin{abstract}
Abstrak: Hadih Maja merupakan kata kiasan nèk tu (nenek moyang) salah satu cara untuk menegur dengan halus dan penuh makna untuk membentuk perilaku siswa sesuai dengan adat istiadat di Aceh. Tujuan penelitian ini untuk mendeskripsikan nilai etika dalam Hadih Maja. Nilai-nilai hasil penelitian ini kemudian dikonstruksikan ke dalam isi dan format proses pelaksanaan teknik diskusi untuk memodifikasi kecakapan sosial siswa. Penelitian ini menggunakan metode penelitian kualitatif dengan proses analisis data Hermeneutika Bersusun. Berdasarkan analisis data terdapat 11 nilai etika dalam Hadih Maja. Nilai-nilai etika dalam Hadih Maja yang didapatkan ke dalam sub tema SOSIAL. Proses pelaksanaan teknik diskusi dalam penelitian ini menggunakan lima tahapan model konseling KIPAS (konseling intensif progresif adaptif dan struktur).
\end{abstract}

\author{
Alamat Korespondensi: \\ Muqarramah Fitri \\ Bimbingan dan Konseling \\ Universitas Negeri Malang \\ Jalan Semarang 5 Malang \\ E-mail: muqarramahfitri46@yahoo.com
}

Teknik diskusi dilakukan dengan cara berkelompok sehingga terjadi interaksi saling tukar pendapat dalam proses pelaksaannya. Percakapan anggota kelompok didalamnya membahas mengenai ide, informasi serta permasalahan yang dihadapi oleh setiap pribadi individu. Teknik diskusi dalam budaya Aceh dikenal dengan duèk mupakat (musyawarah). Musyawarah sudah menjadi tradisi dalam masyarakat Aceh sejak lampau. Duèk artinya (duduk) dan mupakat artinya (musyawarah/pakat), duèk mupakat yaitu suatu kegiatan duduk bersama dan bermusyawarah terhadap pengambilan suatu keputusan atau kegiatan lainnya. Pada proses Duèk Mufakat setiap orang dapat saling bertukar pikiran dan pendapat. Proses pelaksanaan ini, semua anggota diizinkan untuk memberikan pendapat asalkan tidak mengeluarkan ucapan "ekstrim" yang dapat menyakiti hati orang lain (Sektariat Majelis Adat Aceh, 2017).

Duèk mupakat (musyawarah) sebagai pemecah masalah kebuntuan ketika masyarakat dihadapkan dengan masalah, dengan adanya musyawarah dapat menyatukan pendapat dan menjadi tanggung jawab bersama setelah keputusan tersebut diambil. Duèk mupakat (musyawarah) juga menghasilkan solusi yang berupa solutif, keputusan musyawarah tersebut menjadi solusi bersama sehingga diterima oleh semua pihak, hal ini didasari oleh keputusan yang diambil secara bersama melalui musyawarah. Selain pemecah kebuntuan, musyawarah juga menghasilkan istilah perdamaian dan pengurai perselisihan yang terjadi. Jika perselisihan diselesaikan dengan proses Duèk mupakat (musyawarah), maka semua pihak merasa bermartabat karena proses pelaksanaan ini tidak mencari siapa salah dan siapa benar. Melainkan mencari jalan keluar terhadap persoalan yang ada. Musyawarah juga menghasilkan nilai komitmen yang teramat kuat, artinya jika sudah ada kesepakatan, dipegang teguh dan dijalankan sebagaimana mestinya, sedangkan dalam layanan bimbingan dan konseling dilakukan oleh konselor dalam proses dinamika kelompok dengan teknik diskusi.

Diskusi kelompok menjadi salah satu bentuk suatu kegiatan yang dilaksanakan dalam proses konseling maupun bimbingan. Kegiatan ini tentunya dapat melibatkan lebih dari satu individu karena kegiatan ini menjadi suatu alternatif yang dapat memecahkan suatu permasalahan dari individu tersebut. Proses dinamika kelompok dengan penggunaan teknik diskusi membuat siswa lebih mudah menerima serta memahami permasalahan yang dihadapi (Jacobs, Schimmel, Masson, \& Harvill, 2016). 
Penerapan teknik diskusi yang dilaksanakan dalam proses konseling ataupun bimbingan tentunya membuat siswa memperoleh pengetahuan dan informasi terkait bagaimana menyesuaikan diri dalam hal berkomunikasi dalam proses berinteraksi. Hal ini diperkuat oleh hasil penelitian (Maharani, Masya, \& Janah, 2018) bahwa teknik diskusi mampu meningkatkan kecakapan sosial siswa yang rendah, siswa lebih terbuka dalam dinamika kelompok. Hal yang sama juga dibuktikan oleh penelitian (Jones, 2014) bahwa diskusi kelompok mampu membantu siswa untuk saling memahami satu dengan yang lain karena dengan teknik diskusi dapat membuat siswa terlibat dengan ide serta menghasilkan informasi langsung. Penggunaan teknik diskusi dalam proses dinamika kelompok mampu membuat siswa lebih aktif dan juga terbuka dalam proses diskusi yang diterapkan. Tentunya dari teknik diskusi ada nilai posistifnya, namun berdasarkan kenyaatan di lapangan terkait pelaksanaan teknik diskusi masih kurang efektif, serta banyak siswa yang mendapatkan layanan konseling masih mengulangi kesalahan yang serupa. Maka diperlukan suatu kajian budaya untuk di adopsi ke dalam proses pelaksanaannya.

Menurut (Collins \& Arthur, 2007) konselor harus menyadari warisan budaya mereka sendiri. Oleh karena itu, konselor harus mampu untuk memahami cakupan pandangan peserta didik terkait budayanya pada proses pelaksanaan konseling di sekolah. Dengan demikian, diperlukan suatu upaya untuk mewariskan budaya dalam proses pelaksanaan teknik diskusi. Tujuannya agar layanan yang diberikan oleh konselor sesuai dengan kebutuhan siswa di sekolah dan kebudayaan di Aceh. Pada penelitian ini, kecakapan sosial sebagai tema bahasan konseling model KIPAS yakni memodifikasi sensitif simpang orientasi untuk sensitif pada norma dan nilai atau sensitif pada kebaikan maka dilakukan strategi sensitivivasi sosial dengan teknik diskusi. Terkait dengan penjelasan tentang penggunaan konseling Model KIPAS tentunya didukung oleh penelitian dari (Habsy, 2019) bahwa KIPAS adalah upaya untuk merintis tujuan dari model konseling berbasis budaya nusantara yang sudah dirancang agar dapat beradaptasi yaitu dengan manajemen sekolah beserta struktur makro mnasionalnya.

Berdasarkan penjelasan diatas hal tersebut diperkuat oleh pendapatnya (Goleman, 2004) bahwa individu yang terampil itu dalam hal kecakapan sosial tentu memengaruhi suatu keberhasilan dalam segi berkomunikasi serta mampu mengembangkan kepribadiannya untuk dapat, berempati, bekerjasama dan saling menghargai, bilamana mampu menjalankan suatu tindakan yang sesuai dengan norma yang berlaku atau ketentuan yang sudah ditetapkan dikalangan masyarakat salah satunya yang ada dalam petatah petitih Aceh. Dengan demikian, individu memerlukan kecakapan sosial sebagai kemampuan untuk memahami perilaku hubungan yang memengaruhi dengan individu lain serta reaksi yang terjadi di dalam proses interaksi sehingga dapat menerima suatu hal hal positif oleh individu (Agran, Hughes, Thoma, \& Scott, 2016). Hal ini didukung oleh penelitian yang dilakukan (Zach, Yazdi-Ugav, \& Zeev, 2016) terkait kecakapan sosial, hasil penelitian pada proses melakukan perilaku sosial individu melakukan kontak mata, tanggapan berupa verbal maupun non verbal.

Hadih Maja menurut (Ismail, 2018) tutur kata nèk tu (nenek) pada zaman dahulu yang isinya dijadikan sebagai nasihat, larangan serta petunjuk. Hal ini didukung oleh penelitian dari (Hildayani, Narawati, \& Nugraheni, 2019) bahwa hasil penelitiannya terdapat nilai-nilai dalam Hadih Maja, di antaranya kerja sama, loyalitas, kesetiaan, dan tanggung jawab dari nilai tersebut mampu menunjukkan perubahan sikap yang mulanya hilang pada diri siswa dengan adanya pemberian nilai yang ada didalamnya dapat membentuk sebuah perilaku dengan saling peduli dan membantu satu sama lain.

Adaupun pada proses kajian awal yang diperoleh dalam Hadih Maja ditemukan nilai etika yang dapat dijadikan sebagai pedoman bagi remaja di Aceh agar dapat menjadikan kecakapan sosialnya lebih baik dalam berinteraksi. Nilai-nilai etika yang diperoleh dalam Hadih Maja, meliputi (1) nilai jujur, (2) nilai empati, (3) nilai istiqamah, (4) nilai bijaksana, (5) nilai sopan santun, (6) nilai hormat, (7) nilai kepercayaan, (8) tanggung jawab, dan (9) ramah yang dapat menjadi bagian untuk pelaksanaan teknik diskusi yang bermuatan nilai etika yang terdapat dalam hadih maja untuk memodifikasi kecakapan sosial siswa. Nilai-nilai inilah yang dapat menjadi suatu tolak ukur untuk berperilaku serta berkomunikasi yang sopan dan santun sesuai dengan nilai budaya Aceh.

Berdasarkan fakta yang ada di lapangan masih terdapat siswa-siswi yang kecakapan sosial jauh dari kata etika. Hal tersebut terlihat dari gaya tingkah laku dan cara berkomunikasi yang sangat bertentangan dengan ketentuan nilai adat istiadat Aceh. Dengan demikian, disinilah peran bimbingan dan konseling yang dilaksanakan oleh konselor untuk dapat memodifikasi kecakapan sosial yang baik bagi siswa-siswi di sekolah. Berdasarkan uraian latar belakang tersebut, maka fokus pada penelitian ini yaitu mendeskripsikan nilai etika dalam Hadih Maja terkait dengan format dan isi teknik diskusi bermuatan nilai etika dalam Hadih Maja untuk memodifikasi kecakapan sosial siswa.

\section{METODE}

Penelitian ini menggunakan pendekatan kualitatif dengan deskriptif interpretatif. Adaupun tipe dalam penelitian ini yaitu menggunakan tipe Hermeneutika Bersusun (Triple Hermeneutics) atau disingkat dengan AHB. Alasan peneliti menggunakan strategi AHB karena peneliti melakukan penelitian dengan mengkaji tentang nilai etika dalam Hadih Maja sehingga nilai-nilai yang didapat digunakan dalam proses teknik diskusi dalam proses dinamika kelompok. Nilai-nilai tersebut nantinya dideskripsikan menjadi isi dan format dalam proses pelaksanaan teknik diskusi. Lokasi penelitian ini di Kota Banda Aceh yang dikenal dengan sebutan Kuta Raja Seuramôe Mekkah tepatnya di SMA Negeri 11 Banda Aceh yang berada di Jl. Paya Umeet, Desa Blang Cut Lueng Bata Banda Aceh. Sumber data dalam penelitian ini terdiri dari sumber data primer yaitu terdiri dari dua orang informan budayawan (DTWL/IS/L/39/19-06-2019) dan (DTWL/MH/54/L/04-07-2019) dan satu orang konselor (DTWL/YN/38/P/08-07-2019). Selanjutnya yaitu data sekunder yaitu terdiri dari dokumen tertulis yaitu terkait dengan buku Hadih Maja di antaranya Hadih Maja Filosofi Orang Aceh (Norman, 2011) yang diberi kode data 
(DUBP1/HMA/H:140/B:107/2011), memahami orang Aceh (Harun, 2009) diberi kode data (DUBP2/MOA/H:170/B:49/2009). Prosedur pengumpulan data, meliputi wawancara mendalam dan observasi partisipan. Sementara itu, untuk teknik analisis data dalam penelitian ini melalui proses tahapan prosedur analis data Hermeneutika Bersusun (AHB) (Mappiare-AT, 2013). Untuk pengecekan keabsahan data menggunakan triangulasi, validasi intersubjektivitas, dan peer review.

\section{HASIL}

Hasil temuan penelitian ini berupa nilai-nilai etika dalam Hadih Maja. Nilai-nilai etika tersebut berjumlah 11, yaitu (1) kejujuan, (2) empati, (3) Istiqamah/tetap pendirian, (4) bijaksana, (5) sopan santun, (6) tanggung jawab, (7) kepercayaan, (8) hormat, (9) ramah, (10) tolong menolong, dan (11) rendah hati. Adaupun penjelasannya sebagai berikut. Pertama, jujur. Kemampuan individu dalam memberikan sebuah ucapan ataupun informasi yang benar sesuai dengan perbuatannya tanpa dibuatbuat. Kedua, empati. Kemampuan individu dalam memahami serta merasakan perasaan orang lain ataupun kondisi lingkungan sekitarnya yang disertai dengan sebuah tindakan maupun ungkapan. Ketiga, istiqamah/tetap pendirian, kemampuan dalam berperilaku yang konsisten serta tidak berubah-ubah dari segi ucapan ataupun perbuatan. Keempat, bijaksana. Kemampuan seseorang dalam bertindak maupun ucapan dalam mengambil sebuah keputusan tanpa tergesa-gesa yang disertai dengan penuh pertimbangan. Keempat, sopan santun. Kemampuan seseorang dalam berperilaku yang disertai dengan ucapan untuk menghargai serta berakhlak mulia terhadap lingkungan sekitar sesuai tuntutan adat dan istiadat. Kelima, tanggung jawab. kemampuan seseorang dalam berkewajiban untuk melaksanakan tugas pribadi dan bersikap peduli dalam lingkungan sosialnya. Keenam, kepercayaan. Kemampuan seseorang dalam berkomitmen untuk menjaga rahasia serta memberikan keyakinan pada proses menjalin suatu hubungan yang menjadi kesepakatan bersama. Ketujuh, hormat. Kemampuan seseorang untuk menghargai yang tua maupun muda dalam menjaga tutur bahasa serta menghargai sebuah pendapat dalam suatu kelompok. Kedelapan, ramah. Kemampuan seseorang dalam bersikap hangat serta baik budi dalam tutur kata untuk menciptakan hubungan yang akrab serta menyenangkan. Kesembilan, tolong menolong. Kemampuan seseorang dalam kegiatan berpartisipasi serta bertindak untuk membantu meringkan beban orang lain di lingkungan sekitar tanpa adanya kepentingan pribadi. Kesepuluh, rendah hati. Kemampuan seseorang dalam berperilaku untuk menghargai, membantu serta sopan santun ketika bertindak dan bersikap terhadap orang lain dengan tidak ada rasa angkuh dalam hubungan kelompok sosialnya.

Berdasarkan kajian terkait dengan nilai etika dalam Hadih Maja yang diyakini menjadi filosofi masyarakat Aceh hingga saat ini. Secara garis besar, representasi nilai etika yang ada didalam Hadih Maja masyarakat Aceh dibagi ke dalam dua kelompok, yaitu personal dan interpersonal. Sehingga nilai-nilai yang ada dalam Hadih Maja yang mewajibkan untuk dapat diterapkan dalam kehidupan sehari-hari yaitu secara personal atau interpersonal dalam kehidupan sosial. Secara keseluruhannya, nilai etika dalam Hadih Majah ini sebagai keselarasan secara vertikal dan horizontal atau diistilahkan dengan hablumminallah (personal) dan hablumminannnas (interpersonal). Oleh karena itu, nilai-nilai yang ditemukan dapat membentuk kecakapan sosial dengan kriteria sosial, di antaranya situasi interaksi, output interaksi, saluran komunikasi, internal vs eksternal arah ekspresi, andalan diri, langgeng. Berikut secara rinci nilai etika dalam Hadih Maja yang dikatagorikan ke dalam sub tema sosial yang disajikan pada tabel 1.

Tabel 1. Kategori Kecakapan Sosial

\begin{tabular}{lll}
\hline & Nilai Etika & Sosial \\
\hline & Jujur & Situasi Interaksi \\
& Empati & \\
\cline { 2 - 3 } & Hormat & Output Interaksi \\
& Sopan Santun & \\
\cline { 2 - 3 } Teknik Diskusi & Ramah & Saluran Komunikasi \\
\cline { 2 - 2 } & Rendah Hati & \\
\hline & Bijaksana & Internal Vs Eksternal arah ekspresi \\
& Tetap Pendirian & \\
\cline { 2 - 2 } & Tolong & Andalan Diri \\
& Tanggung Jawab & Langgeng \\
\hline
\end{tabular}

Berdasarkan tabel 1 terkait dengan nilai-nilai yang diperoleh agar dapat menjadikan kecakapan sosial tersebut menjadi konstruksi isi dan format teknik diskusi dalam kerangka tahapan konseling model KIPAS (Mappiare-AT, 2017), berikut jabarannya.

Pertama, kabar gembira. Posisi konselor dalam tahap ini yaitu sebagai friends untuk siswa yang akan mengikuti kegiatan konseling ini agar siswa tidak merasakan bahwa konselor sedang mengawasi siswa tersebut. Tahap ini memberikan berupa informasi kabar gembira yang dilakukan oleh konselor dengan surat undangan yang sudah didesain dengan khas Aceh atau bisa juga ketika melakukan proses kegiatan konseling. 
Kedua, integrasi data (internalisasi). Pada tahap ini konselor menentukan suatu tema bahasan sosial kepada siswa yang akan digunakan pada proses pelaksanaan diskusi. Tahap ini konselor serta siswa (konseli) bersama-sama dalam menetapkan poin yaitu dari proses pelaksanaan konseling.

Ketiga, perencanaan kegiatan. Konselor membantu siswa dalam merencanakan suatu tindakan yaitu mengacu pada strategi berupa: kelola diri dan rekonstruksi pribadi, imunisasi diri dan internalisasi berupa nilai budaya, kemudian adanya pemberdayaan (empowering), analisis diri serta situasi, dan yang terakhir yaitu sensitasi sosial (sarasehan). Pada perencanaan kegiatan ini strategi memodifikasinya pada sensitisasi sosial.

Keempat, aktualisasi rencana. Pada kegiatan ini terdiri dari kegiatan peralihan, inti, dan pengakhiran. Kegiatan peralihan berisi tentang: Pada kegiatan ini konselor memberikan pengenalan terkait kartu nilai etika dalam hadih maja, yang dijadikan sebagai media terlaksananya kegiatan inti. Serta menanyakan kesiapan dari setiap anggota kelompok untuk melaksanakan kegiatan tersebut. Kegiatan inti berisi tentang: kegiatan inti merupakan tahap pelaksanaan teknik diskusi dengan penggunaan media kartu nilai etika. Kegiatan ini dimana anggota kelompok mengambil nomor undian di kotak yang sudah disediakan, kemudian siswa membuka nomor undian dan yang dilakukan oleh siswa yang sudah ditunjuk mengambil kartu nilai etika dan mereka membahas topik nilai yang didapatkan, kemudia menggali serta mengeksplorasi hal-hal terkait nilai yang didapatkan dan mengetahui hal-hal konsekuensi yang diperolehnya. Kegiatan pengakhiran berisi tentang: memberikan suatu kesempatan bagi para anggota kelompok untuk refleksi, mengemukakan hasil yang diperoleh.

Kelima, selebrasi/sertifikat. Pada bagian ini, setelah melaksanakan kegiatan, konselor memberikan suatu penghargaan berupa sertifikat atau kata-kata yang hikmat seperti "Alhamdullillah" pada setiap anggota kelompok yang telah mengikuti kegiatan ini dengan penuh suka cita.

\section{PEMBAHASAN}

Pada petatah petitih (Hadih Maja) Aceh terdapat nilai etika yang terdiri dari 11 unsur nilai, yaitu kejujuran, empati, hormat, bijaksana, istiqamah/tetap pendirian sopan santun, kepercayaan, ramah, tanggung jawab, rendah hati, dan tolong menolong. Nilai-nilai etika yang didapatkan sebagai tema sosial dengan penggunaan teknik diskusi dalam dengan langkah KIPAS diharapkan terbentuk kecakapan sosial yang sesuai dengan kriterial sosial yaitu situasi interaksi, output interaksi, saluran komunikasi, internal vs eksternal arah ekspresi, andalan diri, langgeng untuk memodifikasi kecakapan sosial siswa yang sesuai dengan nilai norma dan kehidupan sosial masyarakat.

Pertama, nilai kejujuran. Jujur tentunya akan membuat kepribadian menjadikan sikap yang baik, hal ini dijelaskan oleh (Luther King Jr, 2005) bahwa kejujuran itu tidak hanya dengan orang lain melainkan bagi diri sendiri, baik itu ketika harus mengakui kepada orang lain agar terbentuk kepribadian yang baik bagi orang lain. Hal ini didukung oleh penelitian yang dilakukan oleh (Lee et al., 2014) pemberian nilai kejujuran dengan cerita pinokio dapat memberikan pembiasan individu untuk bersikap jujur dengan teman serta lingkungan sekitarnya yang ditandai dengan ucapan sesuai perbuatan yang disampaikannya. Tentunya keterkaitan dengan sub tema sosial jika siswa memiliki kejujuran yang baik tentunya dapat menciptakan serta menjadikan situasi interaksi sosialnya yang produktif dalam dalam membangun hubungan yang baik.

Kedua, nilai empati menurut (Baron \& Byrne, 2005) dalam empati terdapat dua aspek, yaitu kognitif dan afektif. Pemahaman terkait kognitif yaitu memahami terkait dengan yang sedang orang lain rasakan dan berpikir, sedangkan aspek afektif individu dapat berempati terkait dengan yang dihadapi oleh orang lain. Situasi interaksi yang baik tentunya dengan adanya empati dalam menjalin suatu hubungan sosial dalam berinteraksi agar menciptakan hubungan yang baik serta kondusif antara satu dengan yang lainnya. Hal ini didukung oleh penelitian (Vinayak \& Judge, 2018) adanya empati dalam hubungan menjadi lebih tangguh serta sangat erat kaitannya dengan kesejahteraan dalam sosialnya hingga dapat mengarahkan mereka ke arah pemahaman antar pribadi yang lebih baik.

Ketiga, nilai istiqamah/tetap pendirian ini tentunya memberikan suatu hal yang positif bagi kecakapan sosial siswa dalam keteguhan hati individu dalam bersikap yang diambil adalah benar dan tepat untuk diri individu itu sendiri. Sikap atau perilaku tetap pendirian (istiqamah) menurut (Norman, 1978) jika individu memiliki ketetapan dalam menentukan suatu keputusan maka akan terbentuk tiga aspek berupa bentuk kualitas suatu sikap yang ada pada diri individu tersebut diantaranya pasti, jelas, dan tentunya dapat dipercaya. Tetap pendirian (istiqamah) dapat menjadikan pribadi yang menunjukkan perilaku secara internal dan eksternal yang mengarahkan ekspresi atau perilaku individu tersebut ketika berada dalam lingkungan sosialnya dengan baik.

Keempat, tentang nilai bijaksana yaitu sikap dalam bertindak serta ucapan yang tepat dalam mengambil suatu keputusan. Menurut (Sternberg, 2005) bahwa bijaksana merupakan suatu perilaku atau sikap individu dalam membuat maupun mengambil suatu keputusan yang tepat dan benar. Tentunya internal vs eksternal arah ekspresi dengan adanya nilai bijaksana dengan adanya sikap bijaksana yang dimiliki setiap individu dapat menjadikan pribadinya yang baik serta produktif dalam mengambil suatu tidakan serta ucapan yang bijak dalam hubungan sosialnya.

Kelima, nilai sopan santun bermuatan nilai etika dalam Hadih Maja yaitu sopan santun tidak hanya deri segi perilaku saja, tetapi sopan santun juga harus ada dalam berkomunikasi. Sopan santun yaitu berperilaku yang tidak sombong serta mampu menempatkan posisi diri individu pada tempatnya sesuai dengan keadaan yang ada agar individu itu dapat diterima dalam pergaulan kehidupan sosialnya (Rusyan, 2013). Jika nilai ini diterapkan pada diri siswa-siswi tersebut akan menjadikan output interaksi yang baik dalam membangun hubungan sosial yang efektif. 
Keenam, nilai tanggung jawab yang berarti suatu keyakinan dalam bersikap untuk mengatasi terkait permasalahanpermasalahan yang ada dalam kehidupan agar mampu dihadapinya (Yusuf, 2017). Jika individu memiliki sikap tanggung jawab yang baik maka dalam suatu hubungan situasi interaksi yang dijalani dapat menjalin serta terjaga agar hubungan tersebut menjadi langgeng baik itu pada lingkungan sekolahnya maupun lingkungan sosial individu itu sendiri. Hal ini diperkuat oleh pendapat (Luther King Jr, 2005) menyatakan bahwa individu yang bertanggung jawab tentunya tidak akan membuat suatu alasan atas tindakan terkait apa yang sudah dilakukan oleh individu itu sendiri untuk menyalahkan orang lain.

Ketujuh, kepercayaan atau saling mempercayai tentunya juga bagian dari unsur nilai etika dalam Hadih Maja. Kepercayaan sangat dibutuhkan dalam kehidupan sosial, menurut (Rotenberg, 2010) kepercayaan mencakup diantaranya yaitu berupa harapan, adanya suatu keyakinan, hubungan yang baik tentunya juga dibutuhkan (honesty) antara satu dengan yang lain, dan keterkaitannya emosi (emotionality) individu antar sesama. Individu memiliki kepercayaan dalam diri individu maka individu tersebut ketika berada dalam situasi interaksinya itu ketika dalam menjalin hubugan sosial yang langgeng dengan anatar individu lainnya sehingga saluran komunikasi individu tersebut akan tetap berkembang dengan baik hal ini diperkuat dengan hasil penelitiannya (Molden \& Finkel, 2010) menunjukkan bahwa dengan adanya kepercayaan dalam hubungan persahabatan (sosial) sangat signifikan mampu menjadikan hubungan yang akrab serta juga mampu menjaga kepercayaan yang sudah ada komitmen antara satu sama lain.

Kedelapan, terkait dengan nilai hormat merupakan unsur nilai yang dijadikan sebagai konteks sosial agar saling mengormati satu sama lain. Menurut Rogers dalam (Patterson, 1985) hormat atau respect yaitu suatu kondisi seseorang dalam menghargai terhadap orang lain, tujuan dari respect ini adalah untuk mengubah kepribadian secara konstruktif bagi diri sendiri dan dengan orang lain ketika berinteraksi sosial. Sikap hormat akan menjadikan output interaksi yang baik yang berkaitan dengan kecakapan sosialnya dalam kehidupan sosial baik disekolah serta lingkungan masyarakat dimana individu itu berada.

Kesembilan, sikap ramah bagian dari Hadih Maja yang menjelaskan untuk cara bersikap dalam berkomunikasi dengan orang lain dengan penuh kehangatan. Sikap ramah (agreeableness) menurut Pervin \& Jhon dalam (Hambali, 2013) menyatakan bahwa kualitas suatu individu itu dengan bersikap lembut ketika berkomunikasi serta berperilaku dan berperasaan dengan baik ketika berinteraksi dengan orang lain dalam menjalin hubungan sosial.

Kesepuluh, nilai tolong menolong termasuk ke dalam bagian unsur nilai etika dalam Hadih Maja. Kehidupan sosial akan lebih baik dengan adanya sikap tolong menolong baik itu dalam lingkungan sosial maupun masyarakat. Tolong menolong bagian tingkah laku yang tujuannya untuk membantu satu sama lain. Menurut Baron, dkk dalam (Sarwono, 2015) tolong menolong adalah suatu tindakan individu dalam bertingkah laku untuk membantu orang lain tanpa adanya rasa keuntungan yang diinginkan dari seseorang yang ditolong oleh individu itu sendiri. Individu yang memiliki sikap tolong menolong dapat mengarahkan dirinya dalam berkomunikasi yang baik serta mengandalkan dirinya sendiri untuk membantu orang lain. Hal ini didukung dengan penelitian dari (Wilhelm \& Bekkers, 2010) dengan perilaku tolong menolong dapat meningkatkan hubungan dengan orang lain dan memunculkan rasa empati untuk kepedulian terhadap orang lain.

Nilai terakhir yaitu nilai rendah hati termasuk ke dalam bagian nilai etika yang bermuatan nilai Hadih Maja. Perilaku yang ditunjukkan dengan penuh rasa sopan santun dalam berkomunikasi dengan bahasa yang lembut tanpa adanya rasa angkuh. Tangney dalam (Davis et al., 2017) menyatakan bahwa kerendahan hati merupakan kemampuan individu dalam mengakui kesalahannya, mampu untuk terbuka dengan ide-ide yang baru dengan rasa yang tidak angkuh, untuk dapat berinteraksi dengan bersikap yang tentunya dapat membantu satu sama lain dimana individu itu berada. Tentunya jika nilai ini diterapkan pada diri individu tentunya saluran komunikasi akan menjadi produktif dan berkembang baik dengan adanya sikap rendah hati yang dimiliki oleh setiap individu untuk menjadikan kecakapan sosial dalam situasi interaksi yang efektif. Hal ini didukung oleh hasil penelitian (Permatasari, 2016) dengan penerapan rendah hati setelah dilatih dan diberikan pembiasan mampu meningkatkan sikap rendah hati siswa agar kepribadiannya menjadi pribadi yang baik tanpa adanya sikap tinggi hati. Dengan demikian, melalui nilainilai dalam Hadih Maja yang terdiri dari 11 nilai mampu untuk memodifikasi kecakapan sosial dengan penggunaan teknik diskusi dan tahap-tahap konseling model KIPAS.

\section{SIMPULAN}

Pada nilai etika dalam Hadih Maja ini terdiri dari 11 nilai, yaitu kejujuran, empati, hormat, bijaksana, istiqamah/tetap pendirian sopan santun, kepercayaan, ramah, tanggung jawab, rendah hati, tolong menolong. Nilai-nilai yang didapatkan diharapkan mampu untuk terbentuknya kecakapan sosial dengan kriteria dari kecakapan SOSIAL yaitu Situasi interaksi, terdiri dari kejujuran serta empati. Output interaksi, terdiri dari hormat dan sopan santun. Saluran komunikasi, yang terdiri dari ramah dan rendah hati. Internal vs eksternal arah ekspresi, terdiri dari bijaksana dan tetap pendirian. Andalan diri, terdiri dari tolong menolong. Langgeng, didalamnya terdiri dari tanggung jawab dan kepercayaan.

Adapun saran untuk konselor sekolah bahwa hasil penelitian tentang unsur nilai etika dalam Hadih Maja yang diperoleh agar dapat diterapkan untuk dimodifikasi kecakapan sosial siswa. Sementara itu, siswa-siswi di Aceh diharapkan mampu memahami dan menerapkan nilai-nilai petuah nenek moyang dahulu, yaitu Hadih Maja untuk menjadikan pribadi yang ideal sesuai dengan ketentuan adat istiadat budaya Aceh. 


\section{DAFTAR RUJUKAN}

Agran, M., Hughes, C., Thoma, C. A., \& Scott, L. A. (2016). Employment Social Skills: What Skills Are Really Valued? Career Development and Transition for Exceptional Individuals, 39(2), 111-120. https://doi.org/10.1177/2165143414546741

Baron, R. A., \& Byrne, D. (2005). Psikologi Sosial Psikologi Sosial jilid 2 Edisi Kesepuluh (alih Bahasa:Ratna Djuwita,dkk). Jakarta: Erlangga.

Collins, S., \& Arthur, N. (2007). A Framework for Enhancing Multicultural Counselling Competence. Canadian Journal of Counselling, 41(1), 31-49.

Davis, D. E., Placeres, V., Choe, E., DeBlaere, C., Zeyala, D., \& Hook, J. N. (2017). Relational Humility. Handbook of Humility: Theory, Research and Applications, 105-117.

Goleman, D. (2004). Kecerdasan Emosional: Mengapa El Lebih Penting daripada IQ. Terjemahan Hermaya. Jakarta: Gramedia.

Habsy, B. A. (2019). Scientific Foundation of Nusantara Culture Based Counseling Model Kipas (Konseling Intensif Progressif Adaptif Struktur). European Journal of Education Studies, 5(2017), 213-230. https://doi.org/10.5281/zenodo.2548956

Hambali A, U. J. (2013). Psikologi Kepribadian (Lanjutan). Bandung: Pustaka Setia.

Harun, M. (2009). Memahami Orang Aceh. Bandung: Cita Pustaka Media Perintis.

Hildayani, P., Narawati, T., \& Nugraheni, T. (2019). Study of Instilling the Social Values of Hadih Maja in Tarek Pukat Dance. Advances in Social Science, Education and Humanities Research, 255, 283-286. https://doi.org/10.2991/icade-18.2019.65

Ismail, B. (2018). Perilaku Budaya Adat Aceh, Narit Madja dan Petuah Maja dalam Masyarakat. Banda Aceh: Majelis Adat Aceh.

Jones, J. M. (2014). Discussion Group Effectiveness is Related to Critical Thinking Through Interest and Engagement. Psychology Learning and Teaching, 13(1), 12-24. https://doi.org/10.2304/plat.2014.13.1.12

Lee, K., Talwar, V., McCarthy, A., Ross, I., Evans, A., \& Arruda, C. (2014). Can Classic Moral Stories Promote Honesty in Children? Psychological Science, 25(8), 1630-1636. https://doi.org/10.1177/0956797614536401

Luther King Jr, M. (2005). Helping Your Child Become a Responsible Citizen. In US Department of Education. Retrieved from http://eric.ed.gov/?id=ED503161

Maharani, L., Masya, H., \& Janah, M. (2018). Peningkatan Keterampilan Sosial Peserta Didik SMA menggunakan Layanan Bimbingan Kelompok dengan Teknik Diskusi. Konseli: Jurnal Bimbingan dan Konseling, 5(1), 65. https://doi.org/10.24042/kons.v5i1.2658

Mappiare-AT. A. (2013). Tipe-tipe Metode Riset Kualitatif untuk Eksplanasi Sosial Budaya Bimbingan dan Konseling. Malang: Elang Emas bersama Prodi Bimbingan dan Konseling.

Mappiare-AT.A. (2017). Meramu Model Konseling Berbasis Budaya Nusantara: KIPAS (Konseling Intensif Progresif Adaptif Struktur). Kementrian Riset, Teknologi, dan Pendidikan Tinggi Universitas Negeri Malang.

Molden, D. C., \& Finkel, E. J. (2010). Motivations for Promotion and Prevention and the Role of Trust and Commitment in Interpersonal Forgiveness. Journal of Experimental Social Psychology, 46(2), 255-268. https://doi.org/10.1016/j.jesp.2009.10.014

Permatasari, D. (2016). Tingkat Kerendahan Hati Siswa SMP. Jurnal Konseling Indonesia, 1(2), 83-87.

Rotenberg, K. J. (2010). Interpersonal Trust During Childhood and Adolescence. United States of America: Cambridge University Press.

Rusyan, A. T. (2013). Membangun Disiplin Karakter Anak Bangsa. Jakarta: PT. Pustaka Dinamika.

Sarwono, S. W. (2015). Psikologi Sosial. Jakarta: Salemba Humanika.

Sektariat Majelis Adat Aceh. (2017). Buku Pedoman Peradilan Adat di Aceh untuk Peradilan Adat yang Adil dan Akuntabel. Kabupaten Utara.

Vinayak, S., \& Judge, J. (2018). Resilience and Empathy as Predictors of Psychological Wellbeing among Adolescents. International Journal of Health Sciences and Research, 8(April), 192-200.

Wilhelm, M. O., \& Bekkers, R. (2010). Helping Behavior, Dispositional Empathic Concern, and The Principle of Care. Social Psychology Quarterly, 73(1), 11-32. https://doi.org/10.1177/0190272510361435

Yusuf, LN, S. (2017). Psikologi Perkembangan Anak \& Remaja. Bandung: PT. Remaja Rosdakarya.

Zach, S., Yazdi-Ugav, O., \& Zeev, A. (2016). Academic Achievements, Behavioral Problems, and Loneliness as Predictors of Social Skills Among Students with and Without Learning Disorders. School Psychology International, 37(4), 378-396. https://doi.org/10.1177/0143034316649231 